Vol. XXII No $2 \quad 2016$

\title{
EMPIRICAL RESEARCH ON FINANCIAL STABILITY IN CONTEMPORARY ECONOMIES. ROMANIA CASE STUDY
}

\author{
Leontin STANCIU, Ioan Gabriel POPA \\ "Nicolae Bălcescu" Land Forces Academy Sibiu, Romania \\ leontinstanciu@yahoo.com, popaigabi@yahoo.com
}

\begin{abstract}
Given the profound changes of the financial systems as a result of the technological innovation, the economic liberalization and globalization in the recent decades, and the economic crisis, achieving financial stability is a necessity for the modern economies. In the national economies, ensuring financial stability is a priority for the central banks and the other regulating and supervising authorities. These issues, and others, are the main objectives of our research, and, by referring to the Romanian experience in terms of financial stability, through the conducted research, we intend to contribute to the systematization and the development of knowledge in this area.
\end{abstract}

Keywords: financial system, financial stability, macroprudential policy, central bank, price stability.

\section{Introduction}

Over time, any national economy is subject to "upheavals" and blockages, most of them unpredictable, affecting its operation mechanism in general and the price development and the financial stability in particular. Also, the current global financial crisis, which began in 2007 and whose unintended consequences have not yet been fully eliminated, brought to the forefront of the macroeconomic research and decision making the concept of financial stability and the role of the central bank in providing it.

Lately, providing financial stability, alongside price stability, is a main concern of the central banks which are the core of the national financial systems. Having the responsibility of ensuring price stability through the decisions they make, they contribute to achieving and maintaining financial stability. Furthermore, a stable financial environment is a fundamental prerequisite for price stability.
In a complex and globalized financial environment, assessing and promoting financial stability requires an effective and consistent cooperation, both nationally and internationally, between different supervising authorities (ministries, government agencies, central banks, supervisors and regulators). To this end, a number of central banks, including the National Bank of Romania (NBR) periodically publish reports on financial stability.

These issues, among others, are the main objectives of our research, and through the obtained results, we want to modestly contribute to a better systematization and development of the knowledge in this field.

2. Theoretical Approaches on the Concept of Financial Stability

For the real economy, the financial system plays a vital role and its best functioning facilitates the accumulation of capital, ensures a better distribution of 
risks, guarantees the funding of various investment opportunities, thereby contributing to the economic growth and, ultimately, to increasing the population's standard of living.

In the period preceding the global financial crisis, the international financial system has grown fast but unsustainably, thus aggravating or generating a series of macroeconomic and financial imbalances.

In the context of the global financial crisis, the literature has shown a keen interest in financial stability issues, although it has not reached a common view point concerning its contents.

Unlike price stability, a certain definition of the concept of financial stability has not yet been established at the international level. Moreover, there is no consensus regarding the role of the central banks in providing financial stability, even if their concern in supporting it is no longer a novelty.[1]

Andrew Crockett argues that financial stability is "a situation where the economic performance is not potentially affected by the asset price fluctuations or the inability of institutions to fulfill their obligations"..[2]

Bundesbank believes that the financial stability highlights a steady state of the financial system, which allows it to allocate resources efficiently, to diversify risks, to ensure the settlement of debts, even in financial stress situations, or in periods of substantial structural changes.

The Bank of England considers that the fundamental objective of the financial stability is to ensure the resilience of the financial system, which is a fundamental condition for a sound offer of financial services for the real economy.

The Bank of Holland, according to another official publication, considers that "a sound financial system is able to allocate resources efficiently and to absorb shocks, thus avoiding their having a destructive effect on the real economy or on other financial systems" [3].

The financial system contains the following components, as it results from Figure 1:

- the financial markets (namely the money market and the capital market), which provide the necessary framework for directing the cash flow surplus from creditors to debtors;

- the financial intermediaries (such as: banks and insurance companies), which indirectly make the connection between creditors and debtors;

- the financial infrastructure, which facilitates transfers, payments, transactions, clearances and settlements of securities.

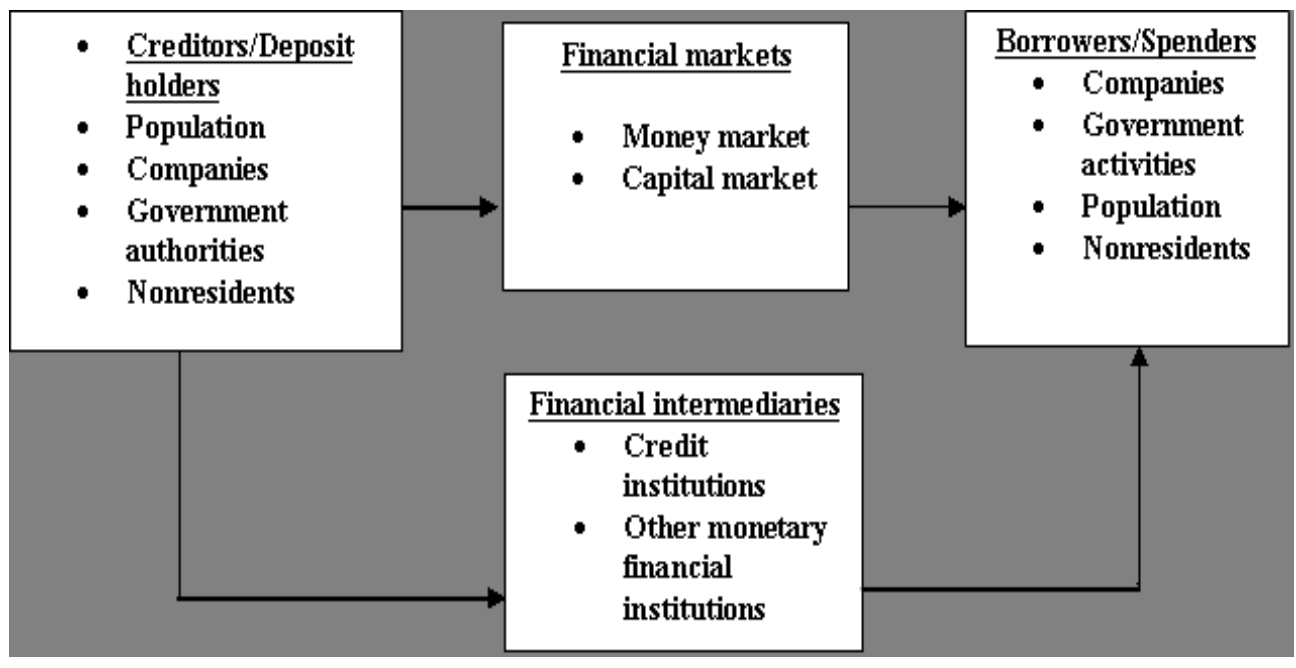

Figure 1- Financial system components 
In its turn, the European Central Bank more comprehensively defines financial stability as a condition in which the financial system is able to absorb financial shocks, mitigating the disruptions of the financial intermediation process, which can hinder directing the savings to investment opportunities [4].

In its first Financial Stability Report, the National Bank of Romania broadly defines financial stability as "that characteristic of the financial system to withstand the systemic shocks on a sustainable foundation, without major disruptions, in order to efficiently earmark resources in the economy and to effectively identify and manage risks" [5].

Also, the NBR governor argues that financial stability is "the situation where the financial system is able to attract and place money funds effectively and to withstand shocks without causing prejudice to the real economy" [6].

Financial stability, according to Schinaşi G., is the state of the financial system where it is able to simultaneously fulfill three essential functions, namely:

- dynamic, efficient and devoid of shocks intermediation of the financial resources (transfer of funds from those who have them to those who use them);

- evaluation, foresight and rigorous management of the risks involved in this process;

- absorption of shocks that the real and financial economy undergoes and/or generates [7].

Taking into consideration the above-mentioned definitions, and the complexity of the topic, we believe that the financial stability is that state in which the economic mechanisms of price formation, financial risk evaluation, division and management, work well enough to help increase the economic performance" [8].

Based on these definitions, we believe that the financial stability highlights the ability of the financial system to efficiently earmark resources and to assess, divide and manage the financial risk through its own corrective mechanisms. Basically, we consider that a financial system is stable when it simultaneously fulfills two fundamental prerequisites, namely:

1. it contributes to increasing the economic performance;

2. it ensures the elimination of the imbalances caused by endogenous factors or by unanticipated adverse events.

\section{Involvement of the Central Bank in Ensuring Financial Stability}

Most experts argue that the central bank has an important role in ensuring financial stability. Although in this field the tasks of the central bank are quite controversial in the literature, there are certain features that contribute to achieving financial stability, such as: supervision;

- banking sector regulation and

- management and oversight of the paying systems;

- deposit guarantee;

- lender of last resort.

Certain phenomena are added to these traditional functions of the central bank that enhance the links between the banking sector and other two important sectors of the financial system (i.e. the financial market and the insurances) such as: the globalization, the deregulation, the innovation and so on. In this context, there are experts who argue that the central bank needs to deal with ensuring financial stability first and thereafter with developing and implementing the monetary policy. [9]

The increased interest of modern central banks in ensuring financial stability derives from the fact that an effective monetary policy is based on predictable transmission mechanisms, which ultimately requires a stable financial environment. On the other hand, the ultimate objective of the monetary policy price stability - is a necessary, but not sufficient, condition for ensuring financial stability. 
Currently, there are authors who claim that the only fundamental objective of the central bank should be price stability, and that there is no compatibility between this objective and the financial stability [10].
As far as we are concerned, we endorse the idea that there is complementarity between price stability and financial stability, and the relationship between them can be pictured as shown below.

\section{Relieving Money Policy from Conflicting Objectives}

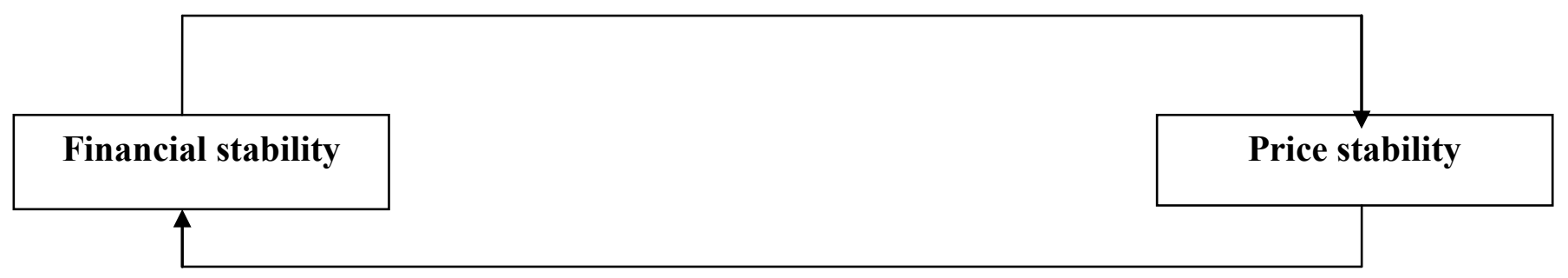

\section{Macroeconomic Balance}

Figure 2 - Relation between financial stability and price stability (Isărescu, 2006,p.1)

We also consider that the main arguments concerning the vital role of the central bank in ensuring financial stability can be summarized as follows:

- the central bank is the only issuer of the "primary" currency, which is the legal and ultimate means of payment;

- the responsibility for the operation of the national payment system (which is the main vector of transmitting and increasing the systemic risk) lies exclusively with the central bank;

- the quality of the banking system operation directly influences the adjustment of the cash flows in the economy by the central bank, according to the objectives of its monetary policy.[11]

\section{The Macroprudential Policy and the} Financial Stability. The Romanian Experience.

The economic reality proves that a stable and sound financial system contributes substantially to the economic growth of a country. Therefore, the financial stability is "a global public good, characterized by non-rivalry and nonexcludability" [12]
Both the market and the central bank and certain state institutions contribute to the financial stability. Ensuring financial stability also requires an international approach in coordinating policies in this field.

The global economic recession resulting from the financial crisis led the central banks to adopt specific measures to stimulate the aggregate demand. Thus, the reference rates decreased gradually, at the same time with the implementation of certain atypical monetary policy measures. These measures have generated a new macroeconomic environment, with nominal interest rates close to zero or even negative, where the vulnerabilities and the sources of systemic risk within the financial system were amplified.

In the current macroeconomic environment, the financial stability plays a central part, due to the macroprudential tools the authorities have available in order to limit the risks and to strengthen the resilience of the financial sector.

In 2010, in order to ensure the stability of the European financial system the European Systemic Risk Board (ESRB) was established. This body is responsible 
for the macroprudential oversight of the financial system in the European Union; it contributes through its recommendations and warnings to the prevention or the mitigation of the systemic risks and to the efficient functioning of the internal market. Thus, the Recommendation ESRB/2011/3 requires the member states to "stipulate in their national regulations the authority which is entrusted with the application of the macroprudential policy, usually represented either by a single institution or by a committee consisting of authorities whose actions have a considerable impact on the financial stability" [13]. By Recommendation ESRB/2013/1, this European body fulfills the macroprudential framework by setting the intermediary objectives and the macroprudential policy instruments.

In Romania, the financial stability is ensured through the combined efforts of several national institutions and through the coordination of the macroeconomic policies. For the implementation of the ESRB recommendations, the Bill on the macroprudential oversight of the national financial system was developed. This bill aims to establish the National Committee for Macroprudential Supervision (NCMS) as an inter-institutional cooperation structure, which is not a legal entity. It will include representatives of the authorities playing an important role in maintaining financial stability in Romania (i.e., NBR, Financial Supervisory Authority and the Government). The fundamental objective of NCMS is to contribute to providing financial stability, including strengthening the financial system to withstand shocks, having among its primary duties the following:

- to identify, monitor and assess the systemic risks;

- to identify the financial institutions and the structures of the financial system which are relevant from a systemic point of view;

- to develop the strategy on the macroprudential policy;
- to issue recommendations and warnings in order to prevent or reduce the systemic risks;

- to monitor the implementation of the recommendations issued by ESRB or NCMS and of the measures adopted by the national authorities, following the recommendations and the warnings issued by the afore-mentioned bodies.

Until the Law on macroprudential oversight of the national financial system is passed, and hence until NCMS is operationalized, the recommendations and the advisory opinions shall be adopted by the National Committee for Financial Stability, established under a cooperation agreement between the National Bank of Romania, the Financial Supervisory Authority and the Ministry of Finance. Within this body, NBR is responsible for setting the strategy in terms of macroprudential policy, within its area of competence. Up to now, NBR:

- has adopted a series of macroprudential measures for crediting the population and the nonfinancial companies;

- has improved its ability to monitor and manage the potentially systemic risks and vulnerabilities within the financial system in Romania;

- has the following intermediary objectives of the macroprudential policy:

- to reduce and to prevent excessive increase in lending and borrowing;

- to reduce and to prevent the excessive imbalance between maturities and the lack of liquidity in the market;

- to limit the concentration of direct and indirect exposures;

- to limit the moral hazard;

- to strengthen the resilience of the financial infrastructures. [14]

\section{Conclusions}

In the context of the economic globalization, of increasing degree of the financial market integration, of the global financial crisis, the financial stability is an important and complex issue both for the 
specialists from the institutions having responsibilities in this field, and for the researchers from the academia. The interest in this issue has been exacerbated by the consequences of the global financial crisis, which revealed a number of weaknesses in the national and also international financial systems. These dysfunctions of the financial systems, due to their instability, had a negative effect on the process of allocating resources and, ultimately, on the economic performance.
In the recent decades, the financial markets have experienced multiple vulnerabilities, which, by rapidly spreading, have increased their fragility. For this reason, currently, ensuring financial stability should be a fundamental goal of public policies, because the stability of the national financial system stimulates the economic development and the improvement of the population's living standard.

\section{References}

[1] Lătea,G.-O., Stabilitatea prețurilor și stabilitatea financiară în activitatea băncilor centrale, in the Economic Library Collection, Economic Issues series, vol.425, Centre for Economic Information and Documentation, p.15.

[2] Crockett, A., The Theory and Practice of Financial Stability, GEI Newsletter, 6, 1997, p1-2.

[3] Wellink, N., Central Banks as Guardians of Financial Stability, The Seminar: Current Issues in Central Banking, Oranjestad, 2002, p.2.

[4] Lătea,G.-O.,op.cit.,p.16.

[5] BNR, Financial Stability Report, 2006, p.7.

[6] Isărescu, M., Stabilitatea prețurilor şi stabilitatea financiară, Dissertation on being awarded the title of Doctor Honoris Causa of the University of Pitești, $8^{\text {th }}$ December 2006,p.8.

[7] Schinasi, G., Defining Financial Stability, IMF Working Papers, 4, 2004, p.82.

[8] Cerna,S.(coord.), Stabilitatea financiară, Timişoara, West University Press, 2008, p.9.

[9] Volcker, P., The Federal Reserve Position on Restructuring of Financial Regulation Responsibilities, Federal Reserve Bulletin,70,1984,p.548.

[10] Jacobson, T., Molin, J., Vredin, A., How Can Central Banks Promote Financial Stability?, Economic Review,2,2001.

[11] Cerna, S.(coord.),op.cit.,p.28.

[12] BNR, Financial Stability Report, 2015, p.133.

[13] BNR,op.cit.,p.137.

[14] BNR,op.cit.,p.140-141. 